\title{
Specifika lyrické poezie jako učební úlohy
}

\author{
Jaroslav Vala \\ Univerzita Palackého v Olomouci, Pedagogická fakulta
}

\begin{abstract}
Abstrakt: Lyrická poezie představuje specifický typ textů, $\mathrm{k}$ jejichž čtení a porozumění je třeba přistupovat jinak než u textů epických, př́padně čistě informačních. Pro žáky i mnohé učitele představuje nejobtižnější typ uměleckých textů, s nimiž se ve výuce setkávají. V článku poukazujeme na souvislost výzkumů zaměřených na porozumění poezii s teorií didaktických znalostí obsahu a otázkami kvality ve výuce literatury. Přinášíme přehled zahraničních teoretických studií a výzkumů sledujících problematiku práce s poezií, specifika její četby a způsob jejímu porozumění. Ukazujeme, že základní míra porozumění poezii je obdobná i přes značné sociokulturní rozdíly mezi čtenáři, nebot' skutečné básnické umění má nadčasový charakter a dotýká se univerzálních lidských témat. Konstatujeme, že toto porozumění se u čtenářù odehrává nikoli na úrovni racionální, nýbrž pocitové, emoční. Skrze emoce jsou někdy žáci schopni dosáhnout hlubokého vhledu do básně, aniž by si to uvědomili a byli schopni sami zformulovat.
\end{abstract}

Kličová slova: literární výchova, lyrická poezie, porozumění textu, recepce poezie, sociokulturní rozdíly, umění

\section{Specifics of Lyric Poetry as a Teaching Task}

Abstract: Lyric poetry is a specific type of the texts, whose reading and understanding should be treated differently than epic texts, eventually information texts. For students and many teachers the poetry is the most difficult type of artistic texts they encounter in the lessons. This paper points to the connection between researches aimed at understanding poetry with the theory of pedagogical content knowledge and quality issues in the teaching of literature. We present an overview of foreign theoretical studies and researches focused on the issue of poetry, specifics of reading poetry and the way of its understanding. We show that the basic level of understanding poetry is similar despite considerable socio-cultural differences among readers because actual poetic art has a timeless character and touches the universal human themes. We note that this understanding takes place not at the rational, but emotional level. Through the emotions the pupils are able sometimes to achieve deep insight into the poem, without realizing it and were able to formulate it themselves.

Keywords: art, literary education, lyric poetry, poetry reception, social and cultural differences, understanding of the text

DOI: $10.14712 / 23363177.2016 .4$

Vzdělávací obor český jazyk a literatura je v RVP ZV zařazen do vzdělávací oblasti jazyk a jazyková komunikace. Tento předmět je specifický tím, že u žáků rozvíjí jejich znalosti mateřského jazyka a komunikační dovednosti. Dovednosti získané ve vzdělávacím oboru český jazyk a literatura jsou předpokladem pro kvalitní vzdě- 
54 lávání v dalších (školních i mimoškolních) oblastech. $V$ literární výchově žáci podle RVP ZV poznávají prostřednictvím četby základní literární druhy, učí se vnímat jejich specifické znaky, postihovat umělecké záměry autora a formulovat vlastní názory o přečteném díle. Žáci na 2 . stupni základní školy tak postupně rozvíjejí své čtenářské návyky i schopnosti tvořivé recepce, interpretace a produkce literárního textu. Pomocí těchto aktivit dospívají k takovým poznatkům a prožitkům, které mohou pozitivně ovlivnit jejich životní postoje, hodnotovou orientaci a obohatit jejich duchovní život. V souladu oficiálními dokumenty se tedy v posledních letech sice $v$ základních školách postupně objevuje myšlenka výuky vycházející z četby žáků a prvků zážitkové pedagogiky, ovšem děje se tak daleko pomaleji, než by bylo žádoucí. Výše uvedené teze o rozvíjení čtenářských návyků však platí pouze tehdy, je-li literární výchova postavena skutečně na četbě a interpretaci textů, které jsou schopny u žáků vyvolat porozumění i emocionální prožitek.

Opačným př́stupem je frontální výklad postavený na kumulaci faktů o autorech a dílech, př́mý kontakt s textem je minimální, př́padně pouze formální. Takové stereotypy, které ovlivňují učitelův prístup k literární výchově, jsou velmi silné a skryté kurikulum tak žákům říká, že literatura je především nuda. Uvedené konstatování potvrzuje Hníkův (2010) výzkum zabývající se pojetím literární výchovy v základních a středních školách. Podle autora výzkumu je v mnohých výpovědích zachycena struktura vyučovací hodiny jako výklad - zápis - četba. Text plní pouze doplňující funkci vzhledem k faktografii, četba je tím marginalizována a redukována. Převažujícím obsahem vzdělání je stále literární historie, zatímco „zážitek z textu a výchova ke čtenářství jsou do současné podoby literární výchovy zahrnuty pouze okrajově (...) a současná literární výchova tak fakticky nemá statut umělecké výchovy“ (Hník, 2010, s. 39). Nabízí se tedy otázka, co a jak dělat v literární výchově jinak, aby žáci mohli zažívat emocionální zážitky z četby a i díky nim osobnostně růst.

Nezpochybňujeme skutečnost, že součástí literární výchovy je i nauková složka (literárněteoretická $i$ literárněhistorická), která mưže vést $k$ chápání díla $v$ širších souvislostech a rozvoji kulturního rozhledu. Tuto tezi plně respektujeme a je implicitně za celým textem přítomna, byt' není jeho hlavním cílem. Jen je třeba zmíněnou naukovou složku nabízet žákům $v$ bezprostřední souvislosti s jejich četbou uměleckého textu a jeho reflexí; související emocionální čtenářský prožitek se může stát zároveň motivací dalšího poznávání. A právě na důležitost role reflexe četby, $\mathrm{k}$ níž ne vždy dostávají žáci prostor, a na roli učitele při interpretaci textu se mimo jiné soustředíme $v$ tomto článku.

Cílem studie je ukázat poezii jako specifický typ textu, $k$ jehož porozumění je třeba přistupovat odlišným způsobem než u textů informačních. Charakterizujeme literární výchovu, vyučovací předmět, který vytváří rámec pro četbu, interpretaci a rozvoj porozumění uměleckým textům, jež představují v daném vyučovacím předmětu svébytný typ učebních úloh. Cíleně se zaměřujeme na poezii, která pro žáky i mnohé učitele představuje nejobtižnější typ uměleckých textů. Poukazujeme na souvislost výzkumů zaměřených na porozumění poezii s teorií didaktických znalostí obsahu a otázkami kvality ve výuce literatury. Přinášíme přehled zahraničních teoretických studií a vý- 
zkumů sledujících problematiku práce s poezií, specifika její četby a způsob jejímu porozumění. V závěru článku se dotýkáme otázky univerzality poezie a odkazujeme na výzkumné šetření sledující mj. rozdíly ve čtenářské recepci a míře porozumění poezii mezi respondenty z různého sociokulturního prostředí.

\section{Specifika literární výchovy}

\subsection{Didaktická znalost obsahu}

Transformací oborových znalostí do podoby vhodné pro výuku se zabývá teorie didaktických znalostí obsahu (DZO) navržená Shulmanem (1987) jako jedna část základní znalostní báze učitele. Klíčovou roli, která je předmětem zájmu badatelů, zde hrají právě transformační procesy, $v$ nichž se učitelovy znalosti obsahu mění do znalostí obsahu vhodných pro vyučování, tj. do didaktických znalostí obsahu. Za důležité považujeme, aby byl učitel literatury (podobně jako jiných předmětů) schopen transformovat své subjektivní znalosti do formy vhodné pro výuku. Učitelovo povědomí o čtenářských preferencích jeho žáků v oblasti poezie mu umožňuje vybírat vhodné básnické texty pro různé kategorie respondentů a zároveň mu může dát odvahu nechat žákům prostor pro jejich samostatnou interpretaci.

Ve vzdělávání učitelů je třeba klást důraz na to, jaké učivo vyberou k výuce a proč konkrétní učivo vyučují právě tak, jak je vyučují. Měli by být vedeni k reflexi výuky a přebírání vlastní zodpovědnosti, nikoli k mechanickému přejímání cizích vzorců výuky i jejího obsahu. Při výběru učiva v literární výchově mohou učitelům pomoci výsledky výzkumů, které sledují žákovské prekoncepty ve vztahu k literatuře (zde konkrétně k poezii) a žákovskou recepci poezie. Posouzení potenciálu učebních úloh různého typu, což je jeden z obecných požadavků na učitele (Janík, 2009), odpovídá v literární výchově výzkum recepce básní. Získané výsledky nás informují, které básně a jakými svými rysy žáky zaujaly více (případně jakou kategorii žáků) a které méně. Tomu můžeme podřídit další výuku, včetně výběru textů a vhodných vyučovacích metod. Práce s recepčně adekvátními texty, které se mohou stát silným motivačním činitelem, pomáhá rozvíjet další znalosti, dovednosti a dispozice žáků. Interpretace poezie bývá u žáků úzce spjata s jejich osobními asociacemi, čímž vycházíme vstříc požadavku na propojení přirozeného světa a světa žáků s oborem. Naplnění těchto požadavků směřuje danou výuku k vyšší kvalitě.

\subsection{Kvalitní výuka v literární výchově}

V současných diskusích o kvalitě vzdělávání dominují především přírodovědné obory a matematika, často $v$ souvislosti s jejich nízkou atraktivitou pro žáky. Prípadně je pozornost věnována jazykovému vzdělávání (srov. Zlatníček, Ducháčková, \& Janík, 2010; Janík, Lokajíčková, \& Janko, 2012). Trochu stranou tohoto zájmu stojí především tzv. výchovné disciplíny (literární, hudební, výtvarná, dramatická a tělesná 
56 výchova), u kterých se obtižně měří jejich výsledky, má-li být vystižena komplexní podoba oborů a oborových cílů. Můžeme sice zkonstruovat testy, které prověřjí vzdělávací kvalitu i v těchto oborech, avšak podobné testy se dotýkají zejména znalostí či výkonů (tělesná výchova). Nesnadno ale zachycují to, co tvoří jejich esenci: rozvíjení estetického vnímání, prožívání; představování kulturních a společenských hodnot; formování osobních hodnot a životních postojů. Výchovné obory mohou být jedním z akcelerátorů osobního zrání. Podobné vlastnosti se však jen stěži zachycují a jsou v rozporu se snahou vzdělávacího systému o homogenizaci a standardizaci pomocí plošného testování (Boughton, 2004).

Kvalitní výuka by neměla pouštět ze zřetele etický, duchovní i duševní rozměr, naopak by měla citlivě přispívat k rozvoji osobní spirituality žáků. Literární výchova a adekvátní umělecké texty nabízejí učitelům $v$ této oblasti velký prostor. Při zkoumání kvality výuky $v$ obecné rovině je třeba nejdříve jasně definovat samotný termín a učinit jej využitelným ve snahách o zlepšování výuky ve školních třídách. Jak uvádějí Janík, Lokajičková a Janko (2012), kvalitu výuky není možno popsat pouhým výčtem charakteristik, tj. že výuka má být jasná, strukturovaná, aktivizující apod. Je třeba specifikovat, čeho konkrétně se mají uvedená adjektiva týkat. Při tomto myšlenkovém postupu se postupně konkretizují určité komponenty výuky a ve vztahu k nim určité charakteristiky. $\vee$ pojetí výše uvedených autorů představuje kvalita výuky především oborovědidaktický problém, nebot’ „výuka má vést k tomu, aby se žáci něčemu naučili, přičemž ve hře je také otázka vhodnosti a schůdnosti cest, které k tomu vedou“ (Janík et al., 2012, s. 28). Jako jednu ze základních komponent kvalitní výuky označují učební úlohy, které v obecném pojetí vyzývají žáka k aktivní učební činnosti; vycházejí z oboru a směřují k cíli učení; zakládají edukativní situaci a podmiňují její formu, organizaci, průběh (Slavík, Dytrtová, \& Fulková, 2010). Bez učebních úloh by výuka přišla o svůj vlastní obsah. Řadíme je tedy mezi základní komponenty výuky, jejichž prostřednictvím se přímo realizuje obsah výuky, a tím se dosahují i její cíle. V literární výchově plní roli učebních úloh především texty umělecké literatury. Vycházíme-li z této teze, pak platí, že nejobtížnějšími úlohami jsou v literární výchově básně.

\subsection{Specifika pedagogické komunikace v literární výchově}

Volba vhodných básní určených $\mathrm{k}$ četbě a didaktické interpretaci, podobně jako volba vhodných metod, má zásadní vliv na míru efektivity dané výuky. Hlubší vhled do recepčního procesu poezie a zjištění konkrétních čtenářských preferencí umožňuje jak volbu adekvátnějších textů, tak i metod výuky. Nejčastější metody používané v literární výchově při interpretaci uměleckého textu (vysvětlování, práce s textem apod.), zaměřené na zkoumání jeho formální stránky a potlačující subjektivní prožitek, totiž většinu žáků od poezie spiše odrazují. Domníváme se, že učitel by neměl žáky zahlcovat formálním rozborem ani svým náhledem na text, ale měl by jim dát možnost $k$ vyjádření, aby nedocházelo $k$ situacím, že spíše opakují učitelovy názory a nezaujímají vlastní hodnotící pozici. Jak podrobněji objasňujeme dále, 
učitel by měl zvládnout specifický typ komunikace. Pike (2000a) označuje tento způsob komunikace a výuky jako „responsive teaching“ a jeho podstata spočívá $v$ tom, že interpretace se začíná na té úrovni, na níž jsou žáci. Koncept skutečně dialogického vyučování při interpretaci textu nemá jasně stanovený výsledek, ten přichází právě s dialogem, $v$ němž učitel reprezentuje pouze jeden $z$ názorů. Tento přístup však není príliš rozšiřrený, nebot' v současné pedagogické komunikaci silně dominuje učitel a struktura této komunikace je výrazně předdefinovaná (Šed'ová, Švařiček, \& Šalamounová, 2012).

Vzhledem ke specifikům komunikace $v$ literární výchově bychom rádi zdůraznili častou negativní reakci učitelů na výpovědi žáků, kteří vnímají učivo jinak než učitelé. Recepce a interpretace uměleckého textu, podobně jako způsob a míra porozumění, jsou svojí podstatou vysoce individualizované. Přesto někteří učitelé reagují na žákovo neotřelé porozumění takovému textu negativně, nebot' jsou jím znejistěni a mají pocit ohrožení své autority. $S$ individuálností porozumění souvisí i učitelovo hodnocení žákovských replik. Na rozdíl od přírodovědných předmětů, kde mívají úkoly často jen jedno řešení, umožňuje báseň různé výklady. Učitel by proto neměl požadovat po žácích, aby textu rozuměli i v detailech stejně jako on. Hodnocení učitele by mělo směřovat k ocenění a povzbuzení žáků, kteří se pokoušejí text interpretovat - každý na základě svých individuálních dispozic. Takové motivující prostředí, kde žáci mohou mluvit otevřeně o svých čtenářských dojmech, vede k přirozenému rozvoji dialogu mezi nimi, v němž může učitel hrát především roli moderátora. Ve výuce literatury je vhodné preferovat konstruktivistické a komunikativní koncepce, zároveň zdưrazňovat sociální dimenzi výuky a symetrický model komunikace. Je žádoucí vytvářet situace, kdy sám žák může vstupovat do role podobné roli experta $v$ daném oboru. Výuku literatury lze tedy chápat jako sociální situaci, do níž žáci přinášejí své osobní zkušenosti, vzpomínky, asociace a na jejich základě pak interpretují text.

\section{Poezie jako učební úloha}

Umělecká literatura, a zvláště poezie, pracuje se specifickým jazykem, v němž se snoubí zkratkovitost a obraznost. Setkávání s poezií a jejím pojímáním jazyka má v sobě potenciál rozvíjet komunikační dovednosti žáků, rož̌iřovat jejich slovní zásobu, usnadňovat recepci uměleckého textu apod. Básnické pojetí jazyka nás znejišt’uje, provokuje, slova nabývají nezvyklých konotací. Toto pojetí nás vede k oslabení rigidního vnímání významů slov a $\mathrm{k}$ větší intelektuální otevřenosti, tj. k vlastnosti, která je nezbytným předpokladem opravdového učení.

Při interpretaci uměleckého textu jsou učitelé, jak jsme již uvedli, často postaveni před úkol reagovat na názory žáků a jejich způsoby porozumění, které se mohou dosti výrazně odlišovat od učitelského pohledu na daný text. $V$ obecnější rovině se dá tato situace vztáhnout na všechna umělecká díla (nejen literaturu) a na otázku, zda umělecké dílo je jen jedno a lidé je pouze různě vnímají anebo zda je umě- 
58 leckých děl tolik, kolik je vnímatelů. Jak konstatuje Kulka (1991), „umělecké dílo je esteticky komunikovaný artefakt, přesněji, soubor všech možností konkrétních realizací uměleckého projektu a jejich recepci“. Z toho vyplývá, že „umělecké dílo existuje ve společenském vědomí jako soubor komunikačních možností (neustále otevřených), které jsou vždy realizovány sociálně historicky a individuálně psychologicky“ (Kulka, 1991, s. 23-24).

Podobný postoj jako Kulka zaujímá k literárnímu textu i Iser (2001), který tvrdí, že „kdyby texty měly skutečně jen ty významy, které vyprodukuje interpretace, už by čtenáři mnoho nezbylo. Mohl by je pouze bud' přijmout, nebo zavrhnout. “ Avšak proces probíhající mezi čtenářem a textem je mnohem složitější, nebot' „text se vlastně k životu probouzí teprve tehdy, když je čten“ (Iser, 2001, s. 40). Text podle Isera musí čtenáři poskytovat prostor pro možné aktualizace, což je umožněno tzv. principem nedourčenosti, který tvoří základní východisko jeho účinku. To znamená, že čtenář musí mít možnost spoluvytvářet význam literárního textu, tj. stanovit nevyslovené vztahy mezi jednotlivými aspekty díla. Důkazem toho je skutečnost, že při druhé četbě literárního díla mu čtenář rozumí svým způsobem odlišně - je totiž vybaven nesrovnatelně větši informovaností, známé události nabývají nových rozměrů, je možno je sledovat z nových hledisek apod. Nic z toho však není př́mo $v$ textu, nebot' ten zůstává neměnný (Vala, 2011).

Recepční zvládnutí epiky se do značné míry zakládá na převaze extenzivní povahy čtení, tj. odkrývání smyslu díla je v epice do jisté míry př́mo úměrné rozsahu přijatých informací. $V$ lyrice však toto pravidlo neplatí, můžeme ji proto označit za řečově nespecifickou. Miko (1988) ji označuje jako umění řečové miniatury. Minimální rozsah lyrického artefaktu je uzpůsobený tomu, aby se daly simultánně v krátkodobé paměti hledat všechny potřebné vztahy a aspekty. Je to artefakt blízký výtvarnému obrazu, který je možno obsáhnout jediným pohledem. Všechny vztahy nejsou hned viditelné, postupně přibývají hledáním, které vyžaduje zpomalené, přerušované a opakované čtení. Každý recipient si literární dílo konkretizuje podle svých dispozicí, tedy vždy z jistého individuálního úhlu. Ve společenském množství těchto individuálních realizací dochází k jejich neutralizaci a ke vzniku objektivní „společné“ představy díla. A právě minimální rozsah lyrických básní, při jejichž četbě je možno simultánně udržet v mysli všechny potřebné vnitřní vztahy, představuje jednu z výhod zkoumání recepce poezie ve srovnání s prózou, např. romány (Vala, 2011).

Lyrická poezie není svou podstatou vždy př́stupná jednoznačným interpretacím. Peskin (2007) ji charakterizuje jako prostředek obohacení života oplodím moudrosti a prostředek sociálního a morálního rozvoje, který vytváři základ kultury. Překrývá se $\checkmark$ ní oblast osobnostního rozvoje jedince a zároveň je nositelkou nadčasového kulturního dědictví. Poezie tak kultivuje čtenáře, zvyšuje v nich povědomí o situacích, stavech a emocích, které u nich mohou nastat; skrze poezii tak poznávají především sami sebe.

Osobnostní růst prostřednictvím poezie se netýká pouze oblasti emocí, morálky a duchovna. Jak uvádějí Kroll a Evans (2008), poezie reprezentuje specifický zpưsob vnímání, při kterém fantazie vyvolává metaforické myšlení. Upevňuje takové myšlenkové spoje, které v nás vyvolávají originální a překvapivé myšlenky a představy. 
Autoři dodávají, že výuka poezie je opodstatněná pro svou schopnost rozvíjet myšlení; zároveň však poezie představuje symbol jazykové komplexity, zdokonaluje tedy naše vyjadřovací schopnosti a generuje estetické potěšení. Rovněž platí, že slova v poezii mohou v kontextu nabývat nových významových odstínů. Poezie je specifický jazyk, jehož smysl je skryt v samotném hledání tohoto smyslu (Eagleton, 2007).

Eva-Woodová (2008) uvádí jako jeden z problémů porozumění poezii fakt, že žáci se mnohdy príliš soustředí na odhalení jednoznačného smyslu $v$ básni. A nemožností jej najít bývají frustrováni. Jejich pojetí jazyka je odlišné od originálního a znejišt’ujícího pojetí básníka. Autorka zdůrazňuje roli čtyř prožitkových strategií při interpretaci básnického textu:

- emocionální konotace slov - jde o zaznamenávání čtenářských reakcí/emocí z klíčových slov básně;

- tělesná zkušenost vyjádřená skrze smysly - např. vizualizace vybraných metafor;

- osobní vzpomínky a asociace - čtenáři čerpají ze svých „předchozích znalosti“, opírají se o své asociace; rozvíjejí své starší emocionální prožitky společně s prožitky aktuálními (vyvolanými básní a novou situací);

- vnitřní rezonance a empatie zažívaná při přednesu básně.

Za užitečnou považuje Eva-Woodová (2008) metodu „myšlení a pocitů nahlas“ (think-and-feel-alouds). Během think-aloud žáci vyjadřují spatra své myšlenky o všem, co čtou. Tento autentický, spontánní zážitek jim může pomoci získat sebevědomí ve výkladu textů spolu se zvýšeným uvědoměním si použitých mentálních nástrojů, které jim pomáhají při čtení.

Pike (2000b) přirovnává báseň $\mathrm{k}$ výtvarnému dílu, jehož smyslem je zkrášlovat prostor - podobně báseň představuje obraz emocionální. Jako vhodné se tedy jeví, aby vyučování literatury bylo zakotveno $v$ recepční teorii chápající text jako stimul, který čtenáře vede $\mathrm{k}$ samostatnému uvažování, při němž vychází ze vzpomínek na osobní zážitky či na jinou přečtenou literaturu vztahující se $k$ dané básni. Básnické interpretaci žáků by měla být přikládána stejná důležitost jako interpretaci učitele, nebot' podle recepční teorie neexistuje jedna jediná výlučně správná interpretace. Vala (2014a, 2014b) ukazuje, jak jsou motivovaní žáci schopni v rámci ohniskové skupiny interpretovat báseň bez výraznější pomoci učitele. Není dobré podceňovat intelektuální kapacitu žáků ani jejich schopnost zapojit se do tohoto procesu. Musíme si ovšem uvědomit, že spolupráce učitele a žáků je možná pouze v pozitivní atmosfére prosycené respektem $\mathrm{k}$ jedinci a jeho názoru.

\section{$2.1 \mathrm{~K}$ možnostem porozumění poezii u žáků}

V předchozím textu jsme zdůraznili potřebu výzkumu žákovských prekonceptů důležitých pro efektivní didaktickou transformaci obsahu. Zaměřme se nyní proto na představy žáků o poezii a její interpretaci, tedy na téma, kterému je $v$ zahraničí věnována v porovnání s tuzemskem zvýšená pozornost. Příčin, proč není poezie mezi žáky oblíbená, bývá uváděna celá řada (srov. Vala, 2011) a většinu z nich můžeme vztáhnout též na české prostředí. Stávající nelichotivý stav tkví v kombinaci řady 
60 faktorů, a jak je patrno $z$ následujícího přehledu aktuálních zjištění v této oblasti, některé se nemění celá desetiletí.

Wisemanová (2011) upozorňuje, že když je žákům nabídnuta možnost psát o tématech, která je zajímají, a mají volnost vyjádřit své smýšlení o sobě i o světě, vzdělávací cíl i literární zážitek se navzájem prolínají. Poezie může představovat most mezi vlastními zážitky žáků a školským kurikulem, mohou se kreativně vyjádřit, rozprávět o svém světě skrze metafory a obrazy. Obsah poezie je rozmanitý a spontánně navozuje různá témata k diskusi. Hennessyová a McNamarová (2011) tvrdí, že v hodinách literární výchovy často není dostatek prostoru pro zapojení kreativity do výuky poezie a že výuce dominuje učitel jako ten, kdo vede výklad a ř́dí celou hodinu. Výzkum zjistil, že cílem takového systému je, aby žáci uspěli v testech, originalita myšlenek, formulování vlastního názoru na poezii se tolik necení. Poezie se tak stává učivem uvězněným $v$ jakémsi boxu, ohraničeném kurikulem, které vede k zvládnutí zkoušky a vědomostem, jejichž odrazem jsou známky z testu.

Učit poezii efektivně znamená nutnost odbourat $\vee$ žácích negativní stereotypy o ní. Jako jednu z metod pozitivně formujících vztah žáků k poezii uvádí Youngová (2007) tzv. poetické kroužky (skupiny), jejichž členové pišou a sdílejí poezii. Poetické kroužky pomáhají žákům, aby se vžili do textu, aby jím byli zaujati a své zaujetí mohli sdílet. Tato technika skupinové práce jim pomáhá stát se tvưrcem i $v$ teoretické rovině, procvičovat svoji kreativitu, chápat čtení a psaní jako navzájem se zrcadlící aktivity a nadchnout se pro sílu slov. Poetické kroužky spojují sílu skupinového učení s individuální kreativní silou každého jedince. Dủležitou roli mají v této oblasti především učitelé, jejich osobní vztah $\mathrm{k}$ poezii a schopnost motivovat žáky. Uvedené faktory mají potenciál zvyšovat úroveň recepce poetického textu. Svensson (1987) uvádí, že žáci jsou jen zčásti schopni interpretovat symboliku v poezii, přičemž jejich schopnost se zlepšuje s přibývajícím věkem. Otázkou náročnosti poezie a kognitivními schopnostmi žáků se zabývají také Peskin, Allen a Wells-Joplingová (2010), kteří konstatují, že recepce poezie je často vnímána jako implicitní proces. Někteří učitelé pak mají pocit, že vývoj poetické gramotnosti je přirozený a individuální, u některých žákủ se objeví, u jiných nikoli. Tento postoj však může $v$ učitelích vyvolávat obavy spojené $s$ marností jejich pedagogického úsilí. A když se tento jejich postoj spojí s pocitem, že na vyučování poezie nebyli sami dost připraveni, může se jejich vztah k poezii stát apatickým. Zmínění autoři se snaží demytizovat logiku symbolické interpretace a ukázat, že se často jedná o procesy explicitní, tj. ovlivnitelné výukou. Na př́kladu metafor ukazují, jak rozvíjení žákovského teoretického poznání může zvýšit sebevědomí žáků a jejich schopnost básně interpretovat. Skupina, která absolvovala hodiny založené na explicitní interpretaci symbolů (jejich analýza byla realizována např. v podobě Vennových diagramů), prokázala vyšší úroveň interpretace i u neznámých a těžkých básní, zatímco kontrolní skupina projevila při stejných instrukcích nižší schopnost interpretace. Naopak žáci z kontrolní skupiny byli interpretace symbolů méně schopní a celá skupina si užila báseň méně. Tento projekt podle autorů dokazuje, že popsané vyučovací metody jsou úspěšné a pěstují ve čtenářích schopnost inter- 
pretace bez redukce jejich zájmu a potěšení. Formalistické pojetí interpretace si zakládá na stylistických prostředcích na úkor osobního zaujetí, zatímco populistické pojetí má tendenci si s textem hrát, na úkor rozvoje kritické gramotnosti. Největší výzvou pro učitele bývá skloubit tyto dva pohledy.

$K$ témuž tématu se autoři (Peskin \& Wells-Jopling, 2012) vrátili ještě jednou a srovnávali výsledky experimentálních a kontrolních skupin ve třech věkových kategoriích (11, 14 a 17 let), přičemž sledovali, jak se liší jejich schopnosti interpretace básnických symbolů. Zjistili, že žáci ve školách tíhnou spiše k prozaickému popisu básní místo nápadité interpretace symbolů. S odkazem na vývojovou psychologii se dále zabývají také tím, zda jsou problémy $v$ symbolické interpretaci u adolescentů způsobeny nedostatkem vědomostí $v$ daném oboru, nebo jen nezralostí psychiky $v$ daném věku a v pozdějších letech se tato schopnost sama rozvine. Výuka zaměřená na symboliku v interpretaci obsahuje „gramatiku“ symbolů, které se v literatuře velmi často vyskytují: např. životní cyklus připodobněný ročním obdobím. Žák, který těmito znalostmi nedisponuje, mívá větši problémy $v$ interpretaci a jeho vývoj v této oblasti bude zpomalený. Mnozí učitelé se však obávají, že tvořením explicitních struktur a procesů v literárním symbolismu zbavíme literaturu prvku zážitku a zábavy. Věří naopak, že znalosti potřebné pro efektivní symbolický výklad se získají nejvíce mlčky skrze neřizené vnímání než explicitním procesem. Van Schooten a de Glopper (2003) nacházejí negativní dopad formálních instrukcí na osobní reakci či čtenářskou odezvu během čtení poezie. Ve svém výzkumu ukazují, že osobní odezva při čtení u žáků v rozmezí sedmého a jedenáctého ročníku při použití metod formálních instrukcí klesá. Žáci pak často přestanou číst úplně pro potěšení, a dokonce při tichém čtení ve škole podvádějí.

Peskin a Wells-Joplingová (2011) se proto snaží zjistit, zda můžeme žáky učit symbolickou interpretaci explicitně tak, abychom zlepšili jejich schopnost objevit během čtení poezie imaginativní a symbolické možnosti básně a zvýšit míru čtenářského porozumění, avšak zároveň jim nebrali chut' do četby a interpretace. Autoři ukazují, že prostřednictvím získaných znalostí v této specifické oblasti básnické symboliky se vypěstovala v žácích schopnost symbolické interpretace. Navíc, explicitní instrukce (tj. výuka) v symbolické interpretaci nesnižila čtenářský prožitek žáků. Výsledky experimentální skupiny byly mnohem pozitivnější než u kontrolní. Jen je podle autorů důležité, aby učitelé dbali na to, jestli jsou žáci, vzhledem ke svému věku, opravdu schopni takové interpretace symbolů, jakou od nich očekávají. Výsledky poslední studie ukázaly, že žáci jsou schopni o básnických symbolech uvažovat relevantně zhruba od věku 11 let.

Vysvětlení, proč experimentální skupina vykazovala výrazně vyšší míru potěšení, může být takové, že žáci si více interpretaci uživali, protože se díky předchozí teoretické průpravě cítili sebevědoměji. Obecně platí, že poezie a jejího výkladu se žáci bojí, považují ji za něco mystického. Autoři uvádějí, že bez správného osvojení strategií a výkladu různých symbolů se žáci nebudou cítit dostatečně sebevědomí v interpretaci, takže ztratí i potěšení z poezie. Podobně Beiswengerová a Grolnicková (2010) našly spojitost mezi sebehodnocením u adolescentů a vnitřní motivací v souvislosti s potěšením z vykonávaných aktivit. A to je právě ten prvek, který zapří- 
62 činil, že ve studii experimentální skupina převýšila ve výsledcích kontrolní skupinu. Důkazy z výše uvedené interdisciplinární studie naznačují, že obtíže adolescentů s nápaditou interpretací poezie nejsou ani tak výsledkem kognitivních vývojových omezení, ale spíše deficitem těchto specifických znalostí.

Některé studie věnující se genderové problematice tvrdí, že podceňování chlapců ve škole a feminizace školství patří mezi velké problémy dnešní společnosti (srov. Weiner, 1994; Wragg, 1997; Foster, Kimmel, \& Skelton, 2001; Maynard, 2005; aj.). Hanratty (2011) v této souvislosti zkoumal, jaké genderové rozdíly se objevují v recepci poezie, sledoval mluvené i psané čtenářské reakce u vybraných žákủ. Zjistil, že drtivá většina žáků nemá ráda poezii, a prokázal rozdíl mezi pohlavími v druhu oblíbené poezie chlapci preferovali maskulinní poezii (válečnou), dívky emociální. Zatímco chlapci tvrdili, že poezie je spiše pro dívky, ty tento názor odmítaly. Výzkum však naznačil, že pracuje-li učitel s poezií citlivě, vybírá vhodné básně a dává žákům prostor pro vyjádření, může poezie zaujmout dívky i chlapce. A jak autor zdůrazňuje, čtenářské reakce chlapců byly stejně nápadité a empatické jako odpovědi dívek, a někdy možná i trochu více.

V literární výchově se žáci setkávají s řadou ukázek ilustrujících nejen různá historická a kulturní období, ale podávajících i obraz mnohdy obtížných životních situací a morálních dilemat. Je třeba usilovat o co největší pluralitu ukázek a zároveň se vyvarovat nenápadného upevňování jejich předsudků a myšlenkových stereotypů. Výběr poezie má děti vést $\mathrm{mj}$. $\mathrm{k}$ respektování a ocenění odlišnosti jiných kultur, což koresponduje s hierarchií výchovných cílů, v níž mají nezastupitelné místo cíle hodnotové. Podobným tématem se zabýval Blackledge (1994), jenž sledoval pozici poezie ve škole a zabýval se zobrazováním rozmanitosti kultur i nebezpečím společenských stereotypů $v$ poezii.

Právě odlišnost rưzných kultur a jejich vliv na způsob porozumění poezii se staly námětem jedné z etap výzkumu Grantové agentury ČR s názvem Výzkum recepce poezie u pubescentních a adolescentních čtenářu, který jsme realizovali v letech 2011-2013 na Pedagogické fakultě Univerzity Palackého v Olomouci. Zatímco většina výzkumů týkajících se míry porozumění poezii, o nichž jsme se zmiňovali v předchozím textu, jsou vedeny po kvalitativní linii, představoval náš výzkum snahu proniknout přímo do recepčního procesu pomocí kvantitativní metody.

\section{$3 \mathrm{~K}$ výzkumu recepce poezie metodou sémantického diferenciálu}

Ve snaze zachytit žákovskou recepci poezie jinak než na základě individuálních interpretací, př́padně kvalitativní výzkumné studie, jsme vytvořili na bázi sémantického diferenciálu (SD) výzkumný nástroj, který sleduje recepci poezie z hlediska tří faktorů: srozumitelnost, hodnocení, působivost (Vala, 2011; 2013). Tyto tři faktory představují měřitelnou složku čtenářské recepce a dohromady mohou představovat celkové porozumění poezii. Jsme si vědomi toho, že estetický zážitek z literárního 
díla (i jiného druhu umění) je nesnadno formulovatelný, a tedy obtížně experimentálně zachytitelný ve své celistvosti. Nicméně jej považujeme za důležité vodítko při volbě adekvátních textů do vyučovacích hodin literární výchovy.

Ve zmíněném výzkumném projektu jsme $v$ obecné rovině sledovali, jak žáci základních a středních škol a univerzitní studenti ve věku 12-21 let čtou a vnímají různé druhy básní, nakolik jsou schopni je interpretovat bez výrazné asistence učitele. Zároveň jsme v longitudinální linii šetření zkoumali, jak lze studentský vztah k poezii ovlivňovat volbou vhodných vyučovacích metod. Výzkumu se zúčastnilo celkem 1088 respondentů, kteří v několika dílčích etapách posuzovali vybrané básnické texty či byli zapojeni do longitudinálního šetření. Detailní informace o metodologii jednotlivých etap výzkumu a jeho výsledcích najde čtenář v publikaci Poezie, studenti a učitelé (Vala, 2013). V kontextu tohoto článku odkážeme pouze na dílčí zjištění týkající se specifické a výzkumně obtížně uchopitelné oblasti - recepce poezie čtenáři v odlišném sociokulturním prostředí. Výzkumník zde naráží na dvojí jazykovou bariéru: v oblasti překladu poezie, který má mnohem častěji podobu přebásnění než doslovného překladu, a v oblasti překladu výzkumného nástroje.

\subsection{Porozumění poezii v rozdílném sociokulturním prostředí}

Jedním z cílů výše představeného výzkumného projektu byla naše snaha ověrit anglickou verzi výzkumné metody na bázi sémantického diferenciálu. Zajímalo nás, zda bude výzkumný nástroj funkční i v jiném jazykovém, kulturním a společenském prostředí, než ve kterém byl původně konstruován. Jazyk je velmi citlivý, překládání jednotlivých adjektiv a posuzování nuancí jejich významů představuje velmi důležitý předpoklad pro úspěšnou transformaci škál SD do jiného jazyka (a kulturního prostředí). Kromě ověřování funkčnosti výzkumného nástroje jsme sledovali rozdíly $\checkmark$ recepci posuzovaných básní, míru jejich porozumění a vše dávali do souvislosti $s$ charakteristikami respondentů. Realizovaný výzkum byl zaměřen na sledování recepce osmi básní českými a americkými vysokoškolskými studenty ve věku 18-21 let a srovnání jejich výsledků.

Výsledky prokázaly schopnost metody SD měřit recepci poezie i $v$ anglické jazykové mutaci. Nepotvrdily se naše obavy, že by se překladem z češtiny do angličtiny a aplikací nástroje $v$ jiném jazykovém, sociálním i kulturním prostředí mohla narušit jeho funkčnost. Z našich zjištění vyplývá, že české respondenty zaujaly především básně, v nichž byl explicitně zobrazen vztah mezi mužem a ženou. Američtí respondenti naopak upřednostnili básně, ze kterých lze cítit především vyrovnanost. Tuzemští respondenti měli více pochopení pro lidskou slabost, váhavost, nerozhodnost a pasivitu, naopak američtí vyzdvihují opak: sílu, rozhodnost a sebevědomí. Do značné míry se jedná o obraz jich samotných, oslovuje je to, co žijí a jak žijí. Potvrzuje se tím jeden z hlavních důvodů, proč lidé čtou uměleckou literaturu. Pomáhá jim orientovat se v sobě. Skutečný umělec dokáže vyjádřit pocity, které sám čtenář hluboko v sobě cítí, alespoň jejich letmé záchvěvy, ale není schopen je verbalizovat. Zajímavé by také bylo zjistit, nakolik se na výsledcích podepsala skutečnost, že 
64 Američané dávají své emoce najevo často a veřejně, zatímco Češi se za své emoce nezřídka spíše stydí. Zde bychom se však dostali na limity možností používaného výzkumného nástroje: sémantický diferenciál je sice schopen měřit čtenářské prožitky $v$ oblasti srozumitelnosti, hodnocení i emocionální působivosti, ale $\mathrm{k}$ tomu nutně potřebuje čtenáře/respondenta, který je ochoten je sdělit. Výchova a v širší míře i kulturní prostředí mají značný vliv na míru vnějších individuálních emocionálních projevů, které nemusí vždy korelovat se stavem lidského nitra (Vala, 2013).

Zahraniční výzkumy ohledně míry porozumění žáků poezii se týkají především toho, jak jsou žáci schopni recipovat texty starší literatury, př́padně velmi odlišných kultur (Benton, 1999; Pike, 2000a; Okunoye, 2004). Zmínění autoři uvádějí, že literatura vzniknuvši před rokem 1900 může být srozumitelná současným čtenářům i přes neznalost detailů dobové kulturní, společenské a politické situace. Jen je důležité $\mathrm{k}$ této poezii nepřistupovat s přebytečnou úctou jako $\mathrm{k}$ objektu literární analýzy, ale číst ji skrze svoji bezprostřední osobní zkušenost. Výsledky našeho výzkumu, kterými mưžeme doplnit předcházející zjištění, ukazují, že různé básně (i současných básníků) mohou podobnou měrou zaujmout i čtenáře $z$ jiného jazykového, kulturního a společenského prostředí. Ukazuje se, že působivě umělecky zpracovaná univerzální lidská témata mohou oslovit nejen čtenáře napříč staletími, nýbrž také napříč různým společenským prostředím.

\section{Závěr}

V článku jsme poukázali na specifika poezie, tedy textů, s nimiž přicházejí žáci $v$ literární výchově do kontaktu, avšak $\mathrm{k}$ jejichž čtení musíme přistupovat odlišně než $v$ př́padě textů čistě informačních. Při četbě poezie není vhodné snažit se porozumět každému verši zvlášt', naopak je třeba vnímat báseň jako celek, jako artefakt podobný obrazu. V opačném př́padě se nám její smysl a emocionální náboj mohou vytratit. Na rozdíl od informačních textů, zvláště odborných, které usilují o preciznost, přesnost, jednoznačnost a konzistenci, není básník podobnými pravidly svazován. Přesnost a preciznost jeho jazyka spočívá v něčem jiném. Často pracuje s nevyřčeným, s tzv. bílými místy, která si zaplňuje čtenář na základě svých životních i čtenářských zkušeností, osobní zralosti, vzdělanosti i momentálního rozpoložení. Obraz básně, který si čtenář vytváří ve své mysli, tvoří syntéza vyřčeného s nevyřčeným, ale za textem latentně přítomným. Básnické pojetí jazyka nabourává naše stereotypní představy o něm, znejištuje nás, oslabuje rigidní vnímání významu slov a silně působí na naši představivost.

Uvedená specifika poezie kladou velké nároky na učitele literární výchovy, především na jeho schopnost ustát situaci, v níž žáci vnímají konkrétní text jinak než on. Ve výuce literatury proto zdůrazňujeme její komunikativní koncepci založenou na symetrickém modelu komunikace mezi učitelem a žáky. Jednotliví účastníci do ní přinášejí své zkušenosti, vzpomínky, asociace, jejichž prostřednictvím pak směřují k porozumění básnickému textu. Zdůrazňujeme, že kvalitní výuka by neměla rezig- 
novat na etický, duchovní i duševní rozměr, naopak by měla citlivě přispívat k rozvoji osobní spirituality žáků. V literární výchově a ostatních esteticky zaměřených vyučovacích předmětech vidíme pro podobné snahy dostatečný prostor.

Vycházíme z předpokladu, že jednu ze základních komponent výuky představují učební úlohy, které vyzývají žáky k učební činnosti a bez nichž by výuka přicházela o svůj obsah. V literární výchově chápeme texty umělecké literatury jako jeden typ učebních úloh, které spoluvytvářejí zároveň obsah i cíl vlastní výuky. Nejobtížnějším typem úloh v literární výchově jsou básně, proto jim věnujeme zvýšenou pozornost.

Výzkumy vztahu žáků k poezii ukazují, že žáci jsou schopni poezii číst, reflektovat, interpretovat. A při vhodně vedené výuce mohou učitelé jejich vztah k poezii dále rozvíjet. Způsob porozumění poezii je specifický a výrazně odlišný od prírodovědných věd, kde často existuje jedna správná odpověd'. Porozumění poezii bývá vysoce individualizované a mnohovrstvé. A jak jsme zjistili ve výzkumu mezi americkými a českými studenty, základní míra porozumění poezii je obdobná i přes značné sociokulturní rozdíly u obou kategorií respondentů. Nadčasová poezie tedy oslovuje ve čtenářích to hluboce lidské. Zároveň platí, že subjektivní pocit neporozumění nemusí být při čtenářském prožitku irelevantní, nebot' cílem porozumění poezii není porozumění racionální.

Poezie, stejně jako jakékoli jiné umění, vyžaduje od recipienta zklidnění, uvolnění a skutečnou vnitřní přítomnost v daném okamžiku. Naše školství, podobně jako celá společnost, je postaveno především na rozumu, na jeho využívání a rozvíjení, méně již na pocitech a emocích. Toto jednostranné zaměření pak vede $k$ jakési setrvačnosti a používání rozumu i v oblastech, kde by neměl být primárně dominantní. A přitomnost rozumu při recepci umění není nezbytně nutná, ba spiše by se dalo říci, že je v přímém protikladu k prožitku umění. Rozumem můžeme zkoušet prožitek vysvětlit a hledat jeho príčiny, ovšem nikdy jej plně nepojmenujeme ani nevrátíme (Vala, 2013).

Z našich zjištění tak vyplynul občasný paradox. Žákovo konstatování, že určité básni nerozumí, neznamená, že jí skutečně nerozumí. Porozumění se odehrává nikoli na úrovni racionální, nýbrž pocitové, emoční. Skrze emoce jsou někdy žáci schopni dosáhnout hlubokého vhledu do básně, aniž by si to uvědomili a dokázali sami zformulovat.

\section{Literatura}

Beiswenger, K. L., \& Grolnick, W. S. (2010). Interpersonal and intrapersonal factors associated with autonomous motivation in adolescents' after-school activities. Journal of Early Adolescence, 30(3), 369-394.

Benton, P. (1999). Unweaving the rainbow: poetry teaching in the secondary school I. Oxford Review of Education, 25(4), 521-532.

Blackledge, A. (1994). Poetry and bias in the primary school. Educational Review, 46(1), 39-45.

Boughton, D. (2004). Assesing art learning in changing context: high-stakes accountability, international standards and changing conceptions of artistic development. In E. W. Eisner $\&$ M. D. Day (Eds.), Handbook of research and policy in art education (s. 585-607). Mahwah, NJ: Lawrence Erlbaum. Dostupné z http: / / www.tes.co.uk/article.aspx?storycode $=54334$.

Eagleton, T. (2007). How to read a poem. Malden: Blackwell Publishing. 
Eva-Wood, A. L. (2008). Does feeling come first? How poetry can help readers broaden their understanding of metacognition. Journal of Adolescent \& Adult Literacy, 51(7), 564-576.

Foster, V., Kimmel, M., \& Skelton, C. (2001). What about the boys? An overview of the debates. In W. Martino \& B. Meyenn (Eds.), What about the boys? Issues of masculinity in schools (s. 1-23). Buckingham: Open University Press.

Hanratty, B. (2011). Poetry and gender: A comparative evaluation of boys' and girls' responses to poetry at key stage 4 in Northern Ireland. Research Papers in Education, 26(4), 413-426.

Hennessy, J., \& McNamara, P. M. (2011). Packaging poetry? Pupils' perspectives of their learning experience within the post-primary poetry classroom. English in Education, 45(3), 206-223.

Hník, O. (2010). Současná podoba výuky literární výchovy podle výpovědí studentů. Český jazyk a literatura, 61(1), 33-39.

Iser, W. (2001). Apelová struktura textů. In M. Sedmidubský, M. Červenka, \& I. Vízdalová (Eds.), Čtenář jako výzva. Výbor prací z kostnické recepční estetiky (s. 31-61). Brno: Host.

Janík, T. (2009). K možnostem rozvíjení učitelových didaktických znalostí obsahu. In T. Janík (Ed.), Možnosti rozvíjení didaktických znalostí obsahu u budoucích učitelů (s. 9-16). Brno: Paido.

Janík, T., Lokajiččová, V., \& Janko, T. (2012). Komponenty a charakteristiky zakládající kvalitu výuky: přehled výzkumných zjištění. Orbis scholae, 6(3), 27-55.

Kroll, J., \& Evans, S. (2008). Metaphor Delivers: An integrated approach to teaching and writing poetry. English in Australia, 41(2), 35-50.

Kulka, J. (1991). Psychologie umění. Praha: SPN.

Maynard, T. (2005). The context: A problem of gender. In K. Topping \& S. Maloney (Eds.), The RoutledgeFalmer reader in inklusive education (s. 83-94). Abingdon: RoutledgeFalmer.

Miko, F. (1988). Umenie lyriky. Bratislava: Slovenský spisovatel'.

Okunoye, O. (2004). The critical reception of modern african poetry. Cahiers d'Études Africaines, 4(176). Dostupné z http://etudesafricaines.revues.org/4817.

Peskin, J. (2007). The genre of poetry: Secondary school student's conventional expectations and interpretative operations. English in Education, 41(3), 20-36.

Peskin, J., Allen, G., \& Wells-Jopling, R. (2010). “The educated imagination”: Applying instructional research to the teaching of symbolic interpretation of poetry. Journal of Adolescent \& Adult Literacy, 53(6), 498-507.

Peskin, J., \& Wells-Jopling, R. (2012). Fostering symbolic interpretation during adolescence. Journal of Applied Developmental Psychology, 33(1), 13-23.

Pike, M. (2000a). Keen readers: Adolescents and pre-twentieth century poetry. Educational Review, 52(1), 13-28.

Pike, M. (2000b). Pupils' poetics. Changing English: Studies in Reading \& Culture, 7(1), 45-54.

Shulman, L. S. (1987). Knowledge and teaching: Foundations of the new reform. Harvard Educational Review, 57(1), 1-22.

Schooten, E. van, \& de Glopper, K. (2003). The development of literary response in secondary education. Poetics, 31(3), 155-187.

Slavík, J., Dytrtová, K., \& Fulková, M. (2010). Konceptová analýza tvořivých úloh jako nástroj učitelské reflexe. Pedagogika, 60(3-4), 223-241.

Svensson, C. (1987). The construction of poetic meaning: A developmental study of symbolic and non-symbolic strategies in the interpretation of contemporary poetry. Poetics, 16(6), 471-503.

Šed’ová, K., Švaříček, R., \& Šalamounová, Z. (2012). Komunikace ve školní třídě. Praha: Portál. Vala, J. (2011). Poezie v literární výchově. Olomouc: Univerzita Palackého v Olomouci.

Vala, J. (2013). Poezie, studenti a učitelé. Recepce, interpretace, výuka. Olomouc: Univerzita Palackého.

Vala, J. (2014a). Prévert's poem Breakfast in the reception of young readers. Procedia - Social and Behavioral Sciences, 6(112), 277-283.

Vala, J. (2014b). The interpretation of an old japanese five-line poem with a focus group method. Procedia - Social and Behavioral Sciences, 6(116), 3816-3819. 
Weiner, G. (1994). Feminisms in education: An introduction. Buckingham: Open University Press.

Wiseman, A. (2011). Powerful students, powerful words: writing and learning in a poetry workshop. Literacy, 45(2), 70-77.

Wragg, T. (1997). Oh boy. The Times Educational Supplement (TES), 16. 5. Dostupné z https:// www.tes.com/article. aspx?storycode $=54334$.

Young, L. (2007). Portals into poetry: Using generative writing groups to facilitate student engagement with word art. Journal of Adolescent \& Adult Literacy, 51(1), 50-55.

Zlatníček, P., Ducháčková, G., \& Janík, T. (2010). Kvalita výuky v oborech školního vzdělávání. In T. Janík, P. Knecht, \& P. Najvar et al., Nástroje pro monitoring a evaluaci kvality výuky a kurikula (s. 33-42). Brno: Paido.

doc. Mgr. Jaroslav Vala, Ph.D., Katedra českého jazyka a literatury Pedagogická fakulta, Univerzita Palackého Žižkovo nám. 5, 77140 Olomouc jaroslav.vala@upol.cz 